\title{
1946 年南海地震直前の南海地域における地震活動の低下
}

\author{
高知大学理学部附属高知地震観測所* 木 村 昌 三 \\ 高知大学** 岡 野 健之助
}

\author{
A Lowering of Seismic Activity in the Nankai District, \\ Southwest Japan, Just before the 1946 Nankai Earthquake
}

\author{
Shozo Kimura \\ Kochi Earthquake Observatory, Faculty of Science, Kochi University, \\ Asakura-honmachi 2-17-47, Kochi 780, Japan \\ and Kennosuke ОкаNо \\ Kochi University, Akebono-cho 2-5-1, Kochi 780, Japan \\ (Received August 8, 1994; Accepted April 13, 1995)
}

\begin{abstract}
We examine the decreasing of seismic activity which occurred in Shikoku, and the Wakayama and Tanba districts prior the 1946 Nankai earthquake, southwest Japan. Considering the effect of the Second World War, the seismic observation for that period by the Japan Meteorological Agency was not in sufficient conditions. Thus, the idea of seismicity lowering on the area has not been generally accepted, notwithstanding some studies on the subject were previously presented. This study proves however the lowering was not caused by the insufficient seismic observation. We give an explanation for the cause of lowering of seismicity. We also showed that the crustal seismic activity in Shikoku in terms of earthquake occurrence gradually decreased with time after the 1946 earthquake. The decrease in seismicity could be anticipated to continue till the next Nankai earthquake in the above mentioned districts. Accordingly, the lowering of seismic activity is expected as a precursor of the great Nankai earthquake, in particular in the Wakayama district where the usual seismic activity is comparatively high compared to other districts.
\end{abstract}

Key words: 1946 Nankai earthquake, Lowering of microseismic activity, Change in number of felt earthquakes.

\section{§1.はじめに}

大地震の予知を目指してその先行現象を捉える研究が 数多く行われてきた結果, 東海地震についてはかなり有 望な成果が得られている[例えば，茂木(1982)］とされ ている. しかし南海地震に対してはいまだ有効な手段が 見いだされていないといってよいであろう。筆者等は 1967 年に地震予知計画による微小地震の観測を開始し て以来一貫して四国の地震活動を研究して来た. その成 果として現在に至るまで四国の地震活動が漸次低下しつ つあることを推定しうるようになった[木村(1992)]. この活動低下が事実であって次の南海地震の直前まで続
くのであれば，この低下を大地震発生前の先行現象とし て役立てることができるのではないかと期待し，1946 年の南海地震発生直前の地震活動を気象庁のデータに よって調べたところやはり活動の低下が見られた。これ と同じょうな活動低下は既に和歌山周辺においても認め られることが報告されている [関谷・涌井 (1972)] が, これは戦中・戦後の社会混乱の影響によるものとして特 に注目されていない.しかし現在四国において進行して いる活動低下を考えると, あながち観測の不備として片 付けてしまうのは妥当ではないと思うので少し詳しく調 ベて見た。

* 干780 高知市朝倉本町 2-17-47

** $=780$ 高知市曙町 2-5-1 


\section{§2. 地震活動}

震源データとしては気象庁の観測結果を䋶䋶・吉井 (1986) がFDにコンパイルした「micro SEIS」を用い た. 1946 年の南海地震発生前後は敗戦時をはさんで極 端に社会が混乱状態にあったので, 気象庁の地震観測む また不充分であった. その間の事情は 1946 年の南海地 震の余震の再調查を行った竹内・他 (1987) によって記 されているが，詳細は不明な点が少なくないようであ る.

先ず Fig. 1 に 1926 年から 1959 年の間に四国から紀 伊半島地域に起こった地震の震央分布を示す. Fig. 1 の 領域における地震活動の時間的推移を Fig. 2 に示す. 東 南海地震と南海地震は特に大きな円で示してあるが, 南 海地震発生直前には四国周辺での地震活動は明らかに低 くなっている.これについては OKANO and KimURA (1979)によっても指摘されているが, その当時四国西部 の観測点のほとんどが停止状態にあったこと［竹内・他 (1987), 浜田 (1994)] を考えると観測の不備が主な原因 であることは当然考えられるところである.

南海地震直前におけるこの特徵が和歌山周辺の地震活

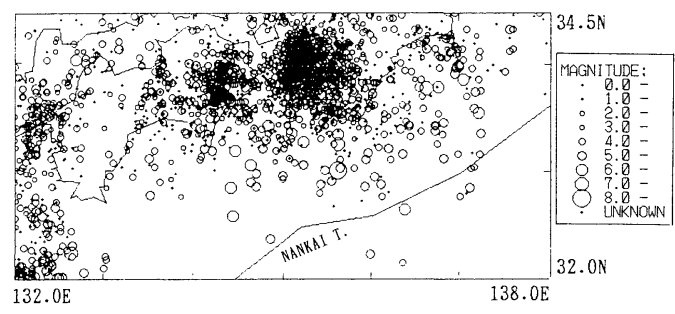

Fig. 1. Epicenter distribution in and around Shikoku and Kii peninsula, southwest Japan adopted in Fig. 2. The data period is from 1926 to 1959 .
動に見られることを指摘した関谷・涌井(1972)は, 1945 年 7 月の和歌山測候所の戦災による焼失を考慮し て, 和歌山に最も近い淡路島の洲本測候所における S-P 時間や和歌山における震度観測に基づいてその可能性を 検証している.ただそのデータの取り扱いについて問題 があるという考えもあるので必ずしも支持されていな い.

Fig. 2 から東南海地震発生直前にもその余震域に同じ ような地震活動の低下を見ることができる。これについ ては力武 (1986) が大志万 (1985) の私信を受けて, 第 2 種空白域と呼んで紹介しているが, この地域はもともと 地震活動が低いということから注目されることが少な い.

以上の現象について筆者等もまた観測の不備を主な原 因とすることを否定するすのではないが，上記 3 例につ いて Fig. 2 を見ると, すでに 1941 年頃から地震活動が 次第に低下しているように見えるので再検討してみる価 值があるものと思う。

1946 年の南海地震に伴って四国周辺ばかりでなく, 近畿地方の丹波山地においても地震活動が高くなったこ とは周知のことであって, 宇津 (1977) はこれを広義の 余震と述べている. ということは, これらの地域で地震 活動が高まったのは南海地震の影響を受けたからと考え られるので, 上記のような発生直前の活動低下がこの地 域にあまた起こったのではないかと期待して四国および 和歌山と併せて調べた。これら 3 地域の範囲を Fig. 3 に 示す. Figs. 4〜6にそれらの地域における地震について 年毎の地震数の変化を区域内の震央分布と共に示す. 図 から明らかなようにいずれの地域においても南海地震発 生直前に活動の低下を見ることができる. なお, 南海地 震の発生が 1946 年 12 月 21 日であるので, これらの図

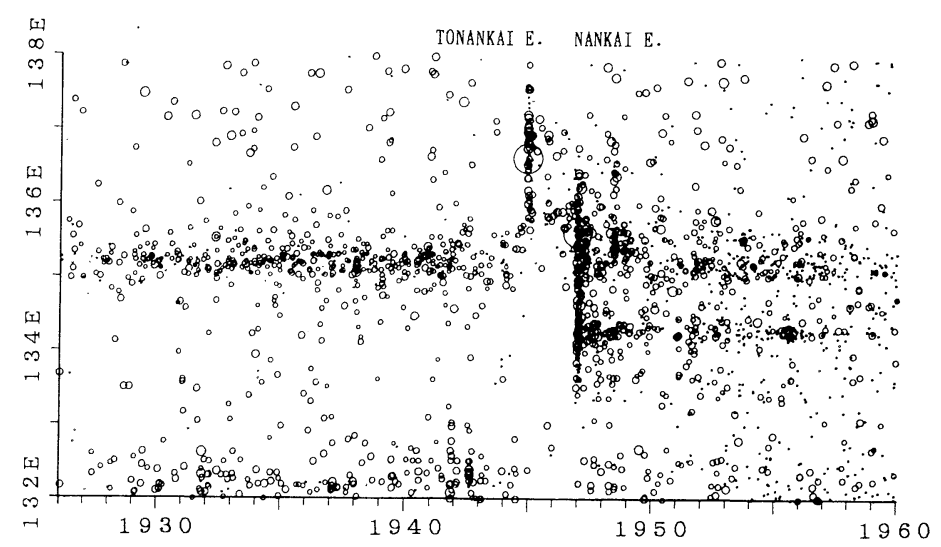

Fig. 2. Space (longitude)-time variation of earthquakes in the area shown in Fig. 1. The upper large circle shows the 1944 Tonankai earthquake and the lower, the 1946 Nankai earthquake. 


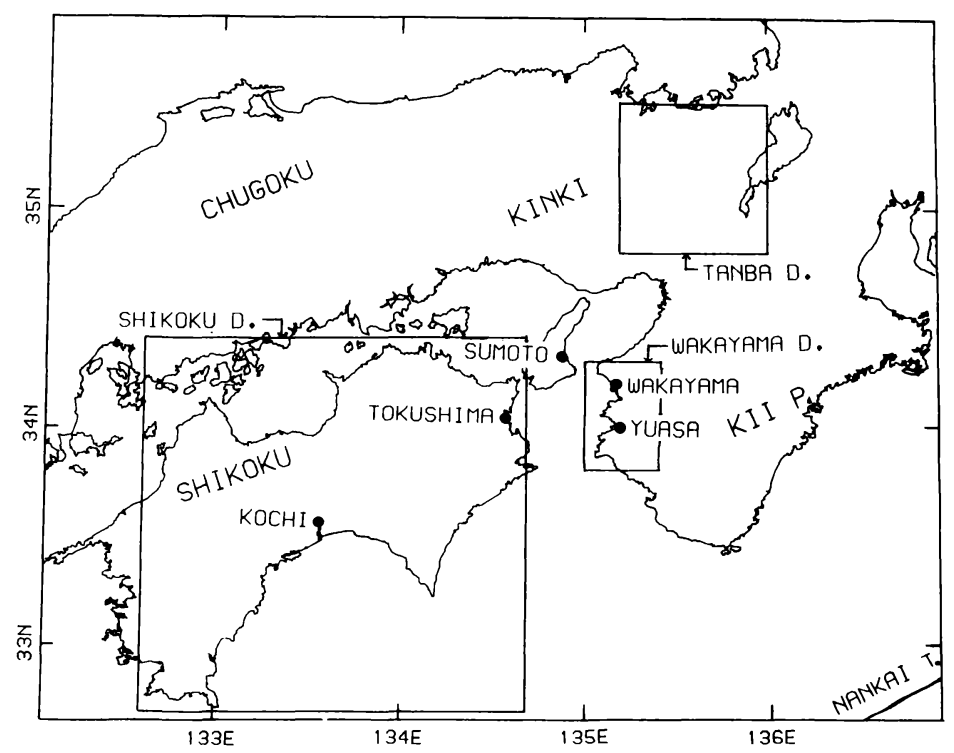

Fig. 3. Map showing three districts set up for examining seismic activities before and after the 1946 Nankai earthquake. Solid circles show the stations used for examining the number of felt earthquakes.
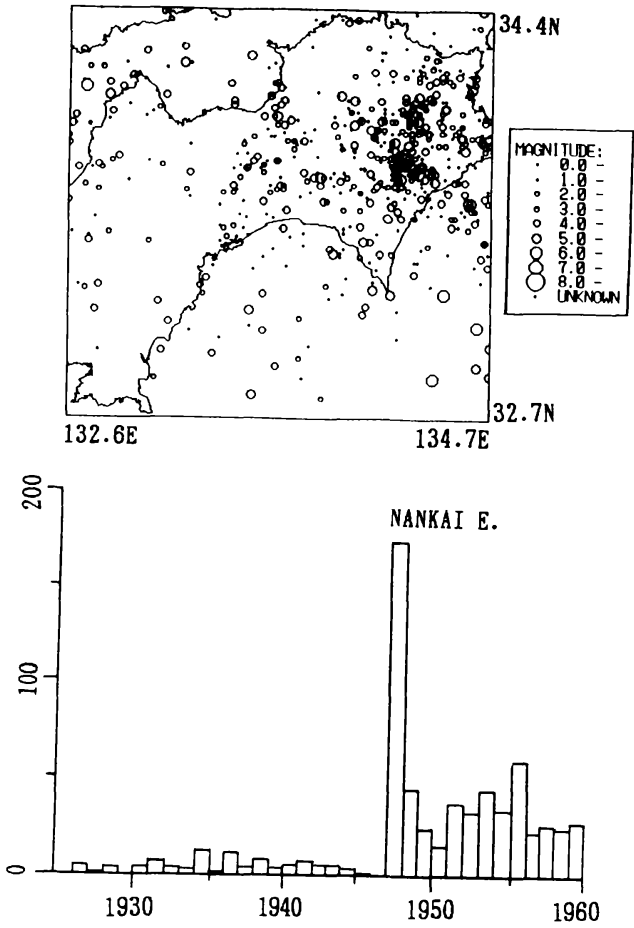

Fig. 4. Epicenters located by JMA in the Shikoku district (upper) and the yearly frequency of those earthquakes (lower).

では 21 日以後 11 日間の地震を翌年の 1947 年に加え て示している.

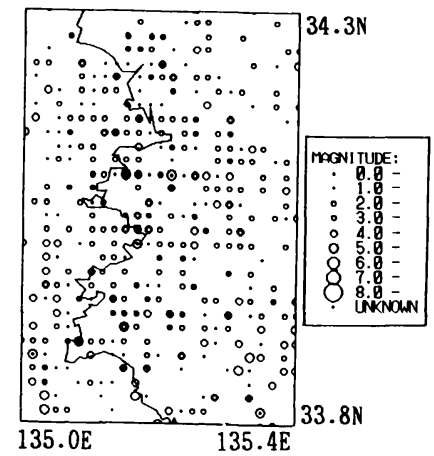

NANKAI E.

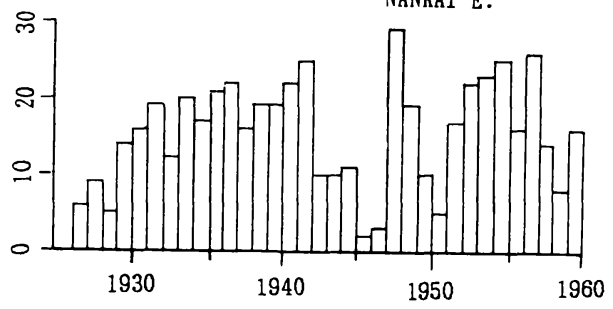

Fig. 5. Same as Fig. 4 expect in the Wakayama district.

§ 3. 四国地方における地震活動の時間的変化

四国地方の地震活動が 1967 年の微小地震観測開始以 来次第に低下しつつあることはこれまでにも発表してき た [例えば, OKANO and KIMURA (1979), 木村 (1992)] が,ここで最近の 1993 年までの観測結果を加えて示 

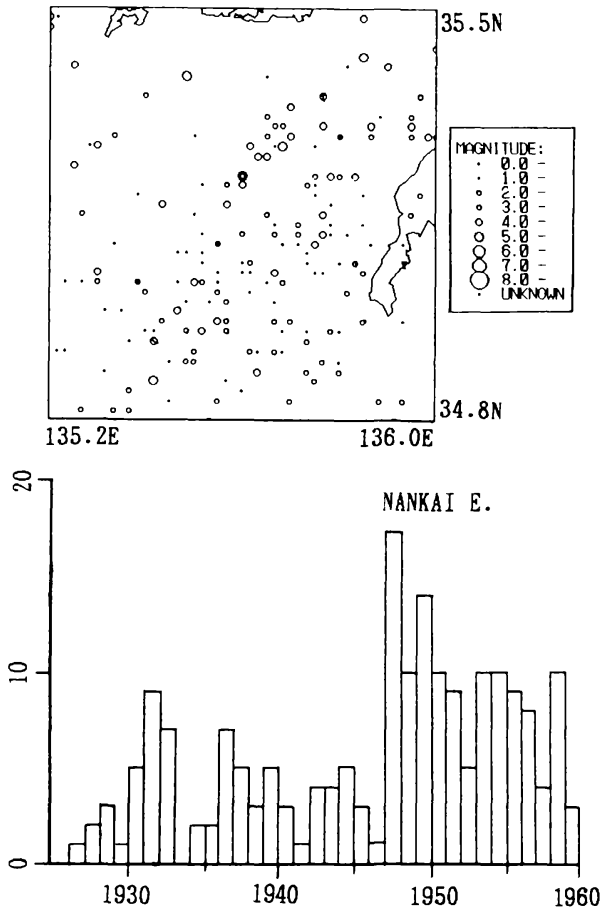

Fig. 6. Same as Fig. 4 expect in the Tanba district.
す. Fig. 7 に地殻地震（主に上部地殼内のいわゆる $V_{p}=$ $6 \mathrm{~km} / \mathrm{s}$ 層内に起こる地震）とマントル地震（マントル 最上部層内に起こる地震）について発生数の時間的変化 を示す．マントル地震については多少の減少傾向は見ら れるもののそれ程の変化が認められない. 一方, 地殼地 震については明らかに活動の低下が認められる.すなわ ち $M$ が 4.0 以上の地震は 1984 年以降全く姿を消し (1994 年 6 月に 10 年ぶりで $M_{\mathrm{JM}}=4.0$ の地款地震が発 生した)， $M$ が 3.5 以上の地震もまた発生しない年が見 られるようになってきている，Mが 3.0 以上の地震の数 が年々減少していくのも一見して明らかである. Fig. 8 は両方の地震についてそれぞれの放出エネルギーの時間 変化を示したものである. 地殼地震はマントル地震に比 べて震源距離が小さいので $M$ の小さい地震がより検知 されやすいために観測される地震数は多いが, 放出エネ ルギーは桁違いに小さいことが分かる. ちなみにマグニ チュード頻度分布における関係式の $b$ 值は地款地震で は 0.98 , マントル地震では 0.72 となり, マントルに比べ 地殼の方が小さい地震の観測される割合は高い［例え ば，木村 (1992)].

次に 1946 年の南海地震発生前後の状況をも見るため に気象庁のデータを使用して微小地震観測開始以前の活 動状況を屯調べた。この場合地震計の感度や震源决定精
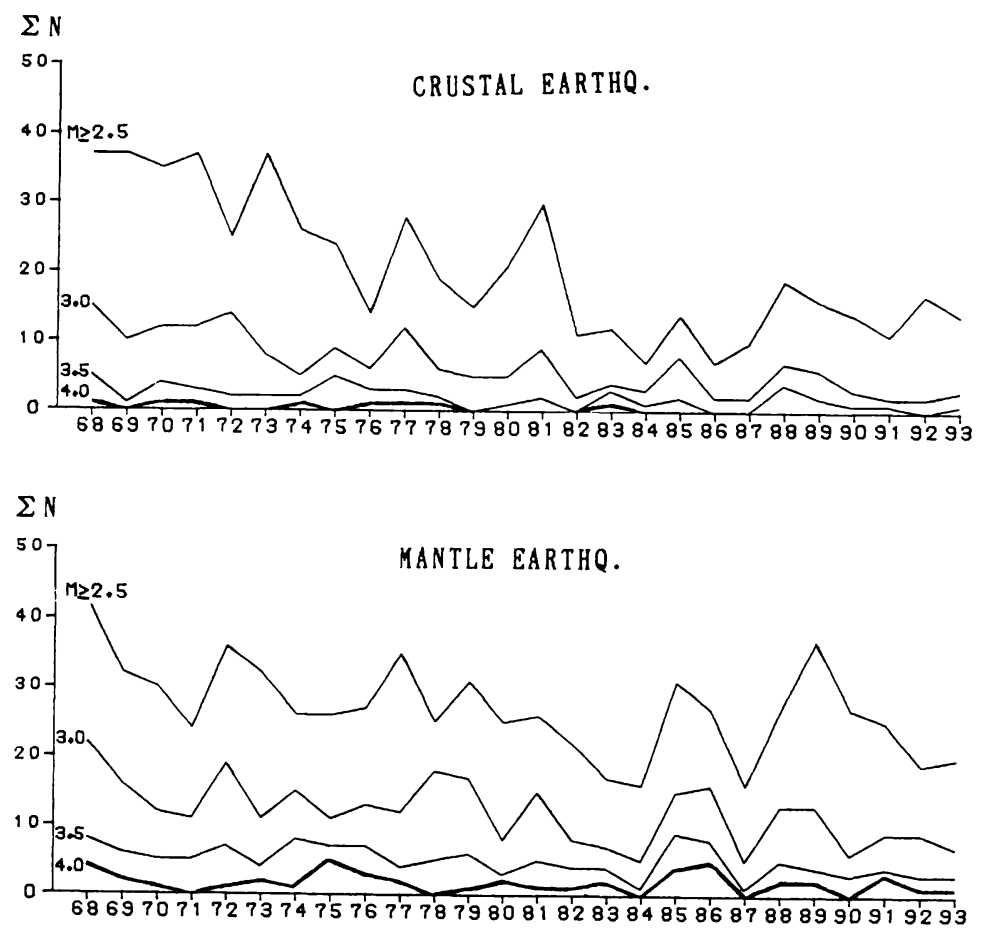

Fig. 7. Yearly variation in seismic activity of the crustal (upper) and mantle (lower) earthquakes $(M \geq 2.5)$ in and around Shikoku obtained by the microseismic observation. 


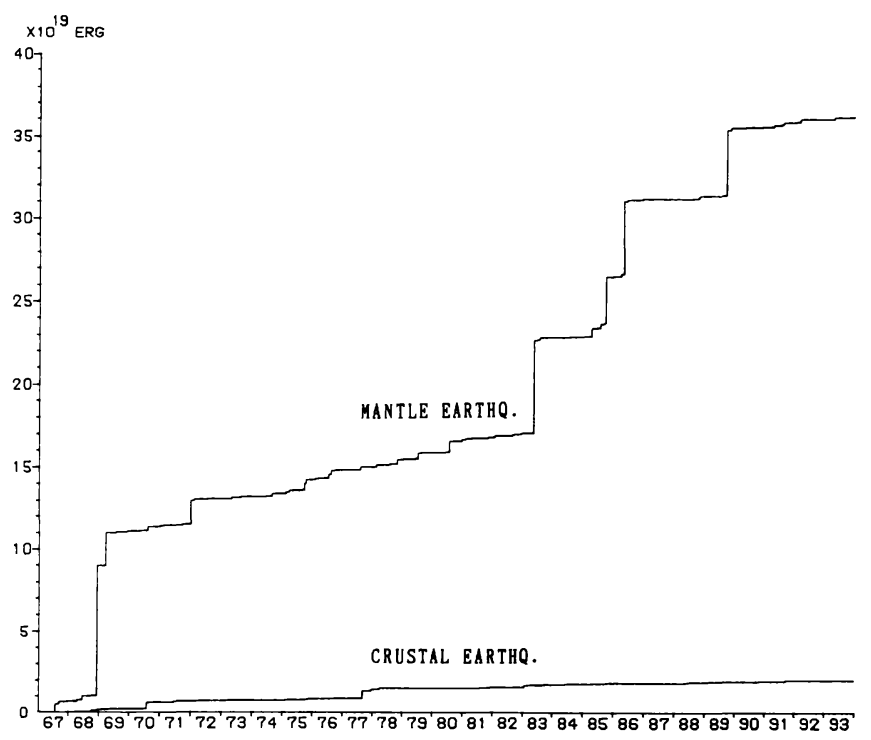

Fig. 8. Accumulated energy release diagrams for crustal and mantle earthquakes.

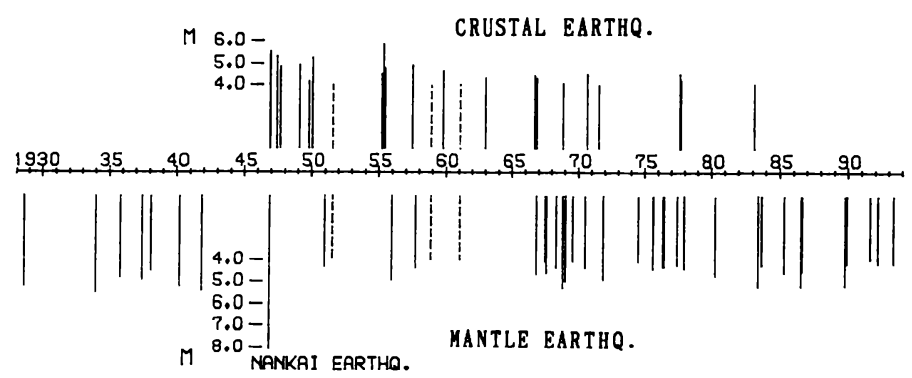

Fig. 9. Variation of earthquake occurrence arranged separately according to the focal depth (after 1967) or the direction of pressure axis (before 1967). Bars drawn upwards and downwards correspond to crustal and mantle earthquakes, respectively. Dotted bars show earthquakes $(M>4.0)$ with unknown focal depths.

度を考えて Fig. 9 のように示した．同図は四国付近にお ける $M$ が 4 以上の地震についてのものである. 同図の 中で上に立てた棒は地款内の, 下向きの棒はマントル内 の地震についてのもので, 上下に記入してある破線はい ずれとも判断しかねる地震である. 1967 年 4 月の微小 地震観測開始以後は高知地震観測所の震源データによっ て区別した。この図からもまた南海地震発生前において は地款地震の活動が極端に低下していて, そして発生直 後から活動か活発になり現在まで漸次低下を続けている ことが明瞭である.この場合, 1967 年以前の気象庁に よって決められた震源の深さからは, 地震が地殼内かマ ントル内かを決めることは困難であることが多いので, そのような場合は P 波初動の押し引きの分布からどち らに属する地震かを判定した。判定は ОкANO et al. (1980)によるメカニズムの解析結果に基づき, 地殸地震 は東西方向, マントル地震は南北方向の $\mathrm{P}$ 軸を持つとい
う性質を利用した。 $\mathrm{P}$ 波初動の押し引きの分布は ICHIKAWA (1965) の論文を引用した.

\section{§4. 讙論}

南海地震発生後に余震またはそれに類する地震活動の あった地域，すなわち四国，和歌山および丹波山地の各 地域において地震発生直前に注目すべき活動低下が見ら れることを示した。しかしこれらの低下は戦争の影響を 受けて観測が不充分であったために震源が決定できない 地震があったからであるとも考えられるのであるが，現 在進んでいる四国における地震活動の低下から次の南海 地震の直前を推測すると， ありえないことであないので 観測の不備だけに帰するのは早計のように思われる.

そこでこのことをさらに気象庁地震課 (1971) および 大阪管区気像台 (1990) の震度観測の報告を用いて検討 した。これらはそれぞれの地域の地震活動だけを示すも 


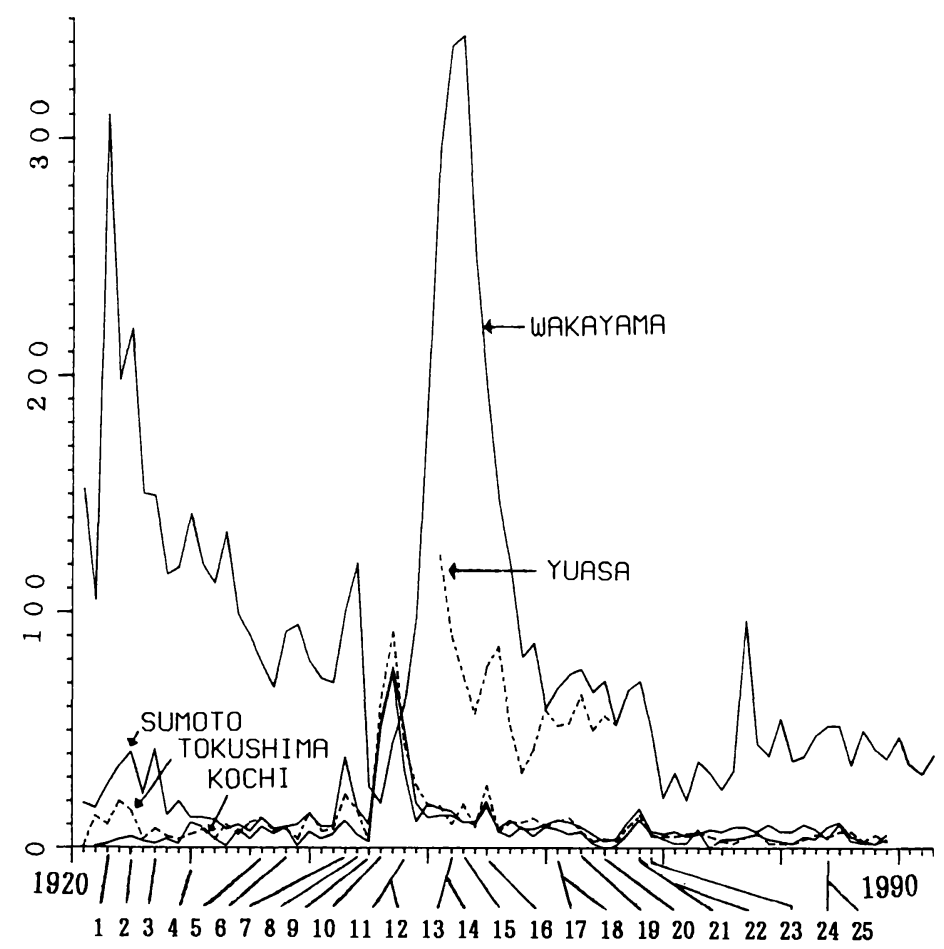

Fig. 10. Temporal variation in yearly number of felt earthquakes in Wakayama, Sumoto, Tokushima and Kochi reported by JMA and in Yuasa by Shinya (1953). Numbers at the bottom correspond to the earthquakes listed Table 1.

Table 1. List of major earthquakes indicated by the numbers at the bottom in Fig. 10.

\begin{tabular}{|r|c|c|l||r|c|c|l|}
\hline No & Date & Mag. & Name of Earthq. & No & Date & Mag. & Name of Earthq. \\
\hline 1 & Sep.1923 & 7.9 & Kanto & 14 & Jul.1952 & 6.8 & Yoshino \\
2 & May 1925 & 6.8 & Kita-tajima & 15 & Nov.1953 & 7.4 & 0ff Boso Pen. \\
3 & Mar.1927 & 7.3 & Kita-tango & 16 & Jul.1955 & 6.4 & S. Tokushima Pref. \\
4 & Nov.1930 & 7.3 & Kita-izu & 17 & Peb.1961 & 7.0 & Hyuganada \\
5 & Feb.1936 & 6.4 & Kawachi-yamato & 18 & Aug.1961 & 7.0 & Kita-mino \\
6 & Jan.1938 & 6.8 & Off Tanabe Bay & 19 & Mar.1963 & 6.9 & 0ff Echizen Cape \\
7 & Sep.1943 & 7.2 & Tottori & 20 & Jun.1964 & 7.5 & Niigata \\
8 & Dec.1944 & 7.9 & Tonankai & 21 & Apr.1968 & 7.5 & Hyuganada \\
9 & Jan.1945 & 6.8 & Mikawa & 22 & Aug.1968 & 6.6 & 0ff W. Ehime Pref. \\
10 & Dec.1946 & 8.0 & Nankai & 23 & Sep.1969 & 6.6 & C. Gifu Pref. \\
11 & Jun.1948 & 6.7 & Hidaka River & 24 & Aug.1984 & 7.1 & Hyuganada \\
12 & Jun.1948 & 7.1 & Fukui & 25 & Sep.1984 & 6.8 & W. Nagano Pref. \\
13 & Mar.1952 & 6.5 & Off Daishoji & & & & \\
\hline
\end{tabular}

のではないが,やはりそれぞれの地域の地震活動を反映 しているし，震度は地震計に見られる故障や感度の変更 には無関係なのでほぼ定常的に観測されたデータとして
有用である. Fig. 3 に黒丸で示した観測点高知, 徳島, 洲本 (淡路島), 和歌山および和歌山県湯浅 [新屋 (1968)ににおいて観測された有感地震についての年毎の 


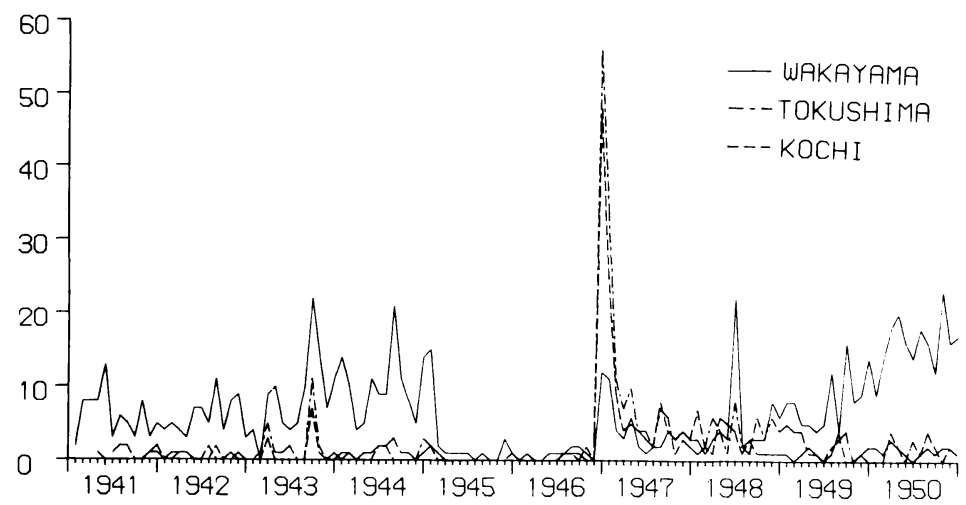

Fig. 11. Temporal variation in monthly number of felt earthquakes in Wakayama, Tokushima and Kochi reported by JMA.

数の推移を Fig. 10 に示す. 参考としてこの期間に起 こった主要な地震を図の最下段にナンバーをつけて示 す.これらのナンバーに対応する地震を Table 1 に示 す.この図から, 南海地震前年の 1945 年における有感 地震は, その前年の 1944 年の東南海地震の余震活動を 考慮すると, その活動が低下していることが推定でき る. 1946 年は和歌山を除いて数が増加しているが, こ れは同年 12 月に起きた南海地震の余震がその年に入れ て数えられているためである，地震発生直前までの地震 活動が極めて低いことは月毎の数の変化を見れば更に明 らかである. Fig. 11 に和歌山, 徳島, 高知における月毎 の有感地震数の変化を示す.一見して東南海地震 (1944 年 12 月）直後から地震が極端に少なくなったことが明 白である.このように南海地震直前の地震活動の低下は これらの震度報告からも伺い知ることができる.

ところで和歌山における変化を見ると他の地域とはか なり様子が異なる点に気づく，中でも南海地震直前の活 動低下がいかにも極端であって, 東南海地震の余震活動 が低下した 2 ケ月後からは有感回数が月に 1 回程度と 急激に減って，その低活動が南海地震まで続いている. また余震が多数観測されたであろう南海地震直後におい てもその数が極めて少なく, 南海地域の洲本, 徳島, 高 知と比べて遙かに少ないことは気になるところである. その後の $1947 \sim 1948$ 年でも地震の数は他の地域と同 じ程度で, 普段の和歌山における高い地震活動を考える と理解し難い部分である.これらは資料の不備によるも のであろうか. あるいは和歌山地域特有のものであるか もしれない．和歌山測候所は 1945 年 7 月の空襲によっ て焼失し, 読み取り原簿を除いて地震計と地震記録紙を 失ったので資料の不備は当然考えられる，ところが幸い にして, 和歌山測候所 (1953) によって「昭和 21 年末の 南海大地震前に極端に減少している」と表現されてお
り，また渡辺 (1952) は前記気象仃地震課のデー夕を使 用して同じ趣旨の論文を書いている.これらの報告は南 海地震後間もない, 記憶も確かであると思われる時期に 書かれているので信頼のおけるものである. 以上のよう に不明確な部分もあるが, 和歌山における南海地震直前 の低地震活動については事実である可能性は極めて高 い.

それでは次に来るべき南海地震までの地震活動はどう であろうか. Fig. 10 の年毎の有感回数の推移を見ると, 南海地震の余震活動が静まり, 現在ではほぼ定常的であ るように見えるが，これらの図の中にも活動の低下が続 いていると見えるものあある. 洲本の年毎の変化は低下 を示しているし，和歌山でも全体的に見ると低下の傾向 を見ることができる. 高知の年変化にはそのような低下 は著しくないが, 有感となる $M$ の大きなものが多いマ ントル地震を含めて数えているこの図には注目される程 の変化が出ないのは不思議ではなく, 地款地震だけを見 れば漸次減少していることは明らかである (Fig. 7). そ れは和歌山についても言えることであって, 地壳地震だ けをとることができれば活動の低下がさらに明瞭になる であろう。

この四国周辺における地殻地震についての活動低下の メカニズムについては既に OKANO and KIMURA (1979) が述べているところであるが,ここで再度考えを示して おく，四国地方においては，地殼地震の $\mathrm{P}$ 軸の方向は $\mathrm{E}-\mathrm{W}$ であり, マントル地震のそれは N-Sである [OKANoet al. (1980)]. マントルの地震を起こす力は, 南 海トラフから沈み込むフィリピン海プレートによって加 えられるとする考えが一般的であるが, 日本列島の南下 によるとする考えあある [岡野(1988)]. いずれにして も大陸と海洋の基盤の間に働く相対的な力によるものと 考えられるが，その方向は N-S から NW-SE である. 
すると地款内に働く $\mathrm{E}-\mathrm{W}$ の力はどこから与えられるの であろうか. 現在主として考えられているのは日本海溝 に東から沈み込む太平洋プレートによる力である。 しか しグローバルなテクトニクスを考えると，その力が薄い 地款にだけ加わり，その直下に接するマントルには影響 が及ばないというのも納得のいかないことである。そこ で次のように考えてみた。

地下の部分にはその上に存在する岩石による圧力が封 圧に近い状態で加わっているとみなせる。そこに前述し た N-S 方向の力がマントルに加わるのであるが, 四国 の下では上部地殼とマントルの間に塑性を持つと考えら れている下部地殼が存在する [岡野・木村 (1983)] ので 力はそのまま上部地壳に伝わらない，室戸岬付近の下に 見られる，上部地殼と最上部マントルがそれを介して接 するようになっている緩衝帯 [木村・岡野 (1992)] を通 して伝達されるであろう。したがってゆっくりとマント ルから加わる力は上部地款にはあまり大きく作用しな い.しかし，この普段㗢いている N-S 方向の力に急激な 変化があると，それが上部地殼に影響を及ぼし，上部地 殸内の地震活動に変化を与えると考える. 南海地震が発 生するとマントルにおける N-S 方向の応力が急激に低 下するので，その作用が上部地殼に及んで地壳内に㗢く $\mathrm{E}-\mathrm{W}$ 方向の応力が相対的に急激に高まり, $\mathrm{E}-\mathrm{W}$ 方向の $\mathrm{P}$ 軸を持つ地款地震の活動が高くなる。これがマントル 内に発生した余震とは別に地款内に誘発された地震であ り，その $\mathrm{E}-\mathrm{W}$ 方向の応力がその後の地殸地震を発生さ せる. そしてその発生に伴って次第に歪エネルギーを失 い，またマントルに働く $\mathrm{N}-\mathrm{S}$ 方向の力の作用が地款に あ加わって, E-W 方向の応力が相対的に次第に小さく なっていくので地款内の地震活動が低下していく．この ように考えると, N-S 方向の応力が非常に高まる南海地 震発生直前においては, 上部地殼の地震活動に著しい低 下が期待できる訳である. マントル地震と地款地震のそ れぞれの P 軸の方向がほぼ直角であるということは両 者の力系が密接な関連を持つとする根拠と考えてよいで あろう。このような特徴は東海地方においてあ見られ， $\mathrm{P}$ 軸がほぼ $\mathrm{E}-\mathrm{W}$ 方向である 1945 年 1 月の三河地震 [ICHIKAWA (1965)］は 1944 年 12 月の東南海地震によ り誘発された地震と考えられる。 また 1707 年の宝永, 1854 年の安政南海地震の直後に高知市周辺において鳴 動を伴った，おそらく震源が極めて浅い地震が，現在で は微小地震もほとんど観測されていないごく浅い部分 $\left(V_{p}=6 \mathrm{~km} / \mathrm{s}\right.$ 層より上部) に発生したと推定される記述 が残っていることも説明できる.

以上の考察から，四国においては主役を演じる起震力 は南北方向の力であると推定するのであるが、これは
Fig. 8 に示されているように, 深さの異なる二つの領域 に発生した地震の放出エネルギーを比較すれば，マント ル地震の方が桁外れに大きいことから疑問のないところ である。一般に南海地震の発生後四国の東・中部におい て地殻地震の活動が高くなった印象が強いので, しばし ば現在でも地凯地震の方が活動が高いと考えられるよう であるが，エネルギー的にはマントル地震の方がはるか に大きいのである.

さて南海地震直前に地震活動の低下が事実起こるもの として, 連鎖的に発生してきた東（南）海地震と南海地 震についてのメカニズムを考えてみる．昭和の場合，こ の二つの地震は余震域が明瞭に分かれていて，それぞれ の余震域は紀伊半島の先端付近で東と西に接している. そこでいま東南海地震が起こったとすると, 紀伊半島の 東側の震源域に働く南北方向の応力は急激に低下するの で，あたかる並列する支えの一方が外れ，力が他の一方 だけにかかる状態となって, 西側の南海地震の震源域に 動く南北方向の応力がより高まる. そのためにその上に ある地款に働いている東西方向の応力が相対的に急激に 低くなって地款地震の活動が急激に低下する. そして南 海地震の震源域には南北方向の力がより強く加わって応 力を高め南海地震の発生を促すと考えれば，二つの地域 に見られる大地震の連鎖的発生も, 直前の地震活動の低 下も一応の理解が得られる.

この東海地震と南海地震の連鎖的発生は安政と昭和の 地震では東海地震の方がそれぞれ一日と二年前に起きて いるが，宝永地震ではその前後関係は明らかでなくほぼ 同時に起きた [宇佐美(1984)] とされている，ただ「山 内氏時代史稿」によると「午/刻に至り暫くゆらりゆら りと静に地震す, 夫より次第にゅり出て天地と一ツに成 様に家も蔵も崩れあやも見合せ難し」とあるので, この 「暫くゆらりゆらりと静に地震す」を東海地震による震 動と解釈すれば, 東海地震の方が数分程度先に発生した と考えられる. そうすると, 宝永, 安政, 昭和の東海と 南海の連鎖地震はすべて東海地震が先に発生している訳 である. いつも東海地震の方が先に起こるという性質が あるのであろうか. といって次の場合もまた東海地震が 先に起こるという保証があるわけではないが，考えに入 れておいてよいかも知れない。

以上のように, 1946 年の南海地震の直前には四国, 和歌山, 丹波山地では極端に地款地震の活動が低下した ことが必ずしも観測の不備によるものではないことが分 かった，それ故次の南海地震の前にも地震活動の低下が 充分期待できるので, 地震発生の時期を予測する手段と して利用する価値があるものと思う. 特に和歌山は微小 地震の頻発地域なので地震活動の変化を監視するには最 


\section{あ適しているであろう。}

\section{§5. おわりに}

これまであまり取り上げられなかった 1946 年の南海 地震直前の地震活動の低下を見直したところ，低下は観 測の不備によるのではなく，事実である可能性の高いこ とが分かった。しかし次の南海地震発生直前における地 震活動のレベルについては手がかりが捰めているわけで はない．地震という現象が確率的な現象なので，その発 生時期を予測するためにはその確率を少しでも高めてい くしかないと考えている.

この研究は多くの方々の援助を受けて行われた．特に 和歌山地方の地震活動については和歌山地方気象台に面 倒な調查を依頼したにもかかわらず，丁重なご回答をい ただいた，気象庁のデー夕等に関しては，気象庁の浜田 信生博士から再三にわたって調査結果と筆者等の考元に ついて有益なコメントをいただいた。また東京大学地震 研究所和歌山地震観測所の中村正夫氏にいただいた和歌 山の地震活動についてのご意見は論文を書き進めていく 上で貴重であった。ささらに東京大学地震研究所の䋶纈一 起, 吉井敏起両博士作成の FD が図の作製を極めて容易 にし，それがこの研究を行うきっかけを作ってくれたと いってよい。これらの方々に心から御礼申し上げます。 高知大学高知地震観測所の川谷和夫技官による長年にわ たる細心な観測と記録の読み取りは地震活動の変化を調 べる上で欠くことのできないものでした.

この論文は青木治三（名古屋大学理学部）, 安藤雅孝 （京都大学防災研究所）両查読者の適切なご指摘によっ て問題点をより深く掘り下げることができ，いろいろな 点で改善されました，查読者のお二方に厚く御礼を申し 上げます。

\section{文献}

浜田信生, 1994, 私信.

ICHIKAWA, M., 1965, The mechanism of earthquakes occurring in central and southwest Japan and some related problems, Pap. Met. Geophys., 16, 104-156.

木村昌三，1992，四国付近における地震活動の経年変 化, 地震学会講演予稿集, No. 2, 73 .

木村昌三・岡野健之助, 1992, 四国におけるマントル地 震の特徵, 高知大学理学部紀要, 13, 物理学編, 1-12. 気象庁地震課, 1971 , 日本における震度観測の記録, 気 象庁技術報告第 76 号, 気象庁, $222 \mathrm{pp}$.

紾䋶一起・吉井敏赾, 1986, 地震データベース利用シス テムの開発 $(2)$ - $\mathrm{PC}$ への移植一, 地震学会講演予稿 集, No. 2, 247.

茂木清夫, 1982, 日本の地震予知, サイエンス社, 352 pp.

岡野健之助, 1988 , 四国の地震, 土佐出版社, $210 \mathrm{pp}$.

OKANO, K. and S. KimURA, 1979, Seismicity characteristics in Shikoku in relation to the great Nankai earthquakes, J. Phys. Earth, 27, 373-381.

岡野健之助・木村昌三， 1983 , 四国地方における $V_{p} / V_{s}$ と地震活動との関連, 地震 2, 36, 431-437.

Okano, K., S. Kimura, T. Konomi and M. Nakamura, 1980, Focal mechanism in Shikoku, Japan inferred from microearthquake observations, Mem. Fac. Sci. Kochi Univ., 1, Ser. B, 1-13.

大阪管区気象台，1990，近畿・中国・四国の有感地震， 大阪管区気像台, $211 \mathrm{pp}$.

力武常次, 1986 , 地震前兆現象, 東京大学出版会, 232 pp.

関谷 溥・涌井仙一郎, 1972, 大地震前後の地震活動 (III) (1944 年東南海地震, 1946 年南海道地震), 地震 予知連絡会会報, 7, 50-54.

新屋兼次郎, 1968, 和歌山県湯浅における地震観測, 地 震研彙報, 46, 161-173.

竹内 新・吉川一光・浜田信生, 1987, 1946 年南海道 地震の余震分布の再調查, 地震学会講演予稿集, No. $1,15$.

宇佐美龍夫, 1984, 宝永地震の震度分布, 地震予知連絡 会会報，31，468-472

宇津徳治, 1977, 地震学, 共立出版, $302 \mathrm{pp}$.

和歌山測候所, 1953, 紀伊半島の地震について, 紀淡海 峡頻発地震調查報告, 大阪管区気象台， 35-43.

渡辺正之, 1952, 和歌山の地震之地盤变動, 研究時報, 4. 733-736. 